\title{
Superimposed ice in glacier mass balance on the Tibetan Plateau
}

\author{
Koji Fujita, Katsumoto Seko, Yutaka Ageta \\ Institute for Hydrospheric-Atmospheric Sciences, Nagoya University, Nagoya 464-01, Japan \\ Pu Jianchen and Yao Tandong \\ Lanzhou Institute of Glaciology and Geocryology, Chinese Academy of Sciences, Lanzhou, China
}

\begin{abstract}
The relations between mass balance and meltwater refreezing were examined on the basis of glaciological observations carried out in summer 1993 on Xiao Dongkemadi Glacier, Tanggula Mountains, central Tibetan Plateau. On this glacier, a part of meltwater refreezes at the snow/ice interface as superimposed ice. The amount of superimposed ice formation was determined by both meltwater supply and temperature condition of the glacier. Snow-layer thickness on the glacier ice body is less than $2 \mathrm{~m}$, even in the higher accumulation zone. About $60 \%$ of meltwater generated in the accumulation zone for the period May-September was trapped at the snow/ice interface by refreezing, and was not discharged out of the glacier. About $26 \%$ of accumulated snow to the glacier surface was replaced on the snow/ice interface by refreezing in the accumulation zone. These facts indicate that superimposed ice formation is quite significant for water retention in glaciers under low-precipitation conditions.
\end{abstract}

\section{INTRODUCTION}

Meltwater refreezing plays an important role in the mass balance of sub-polar glaciers whose annual mean ice temperature is below $0^{\circ} \mathrm{C}$. Quantitative studies on meltwater refreezing have been made in Arctic Canada (Baird, 1952; Ward, 1952; Koerner, 1970), Alaska Wakahama and others, 1976; Trabant and Mayo, 1985), Greenland (Braithwaite and others, 1994) and central Asia (Bazhev, 1973).

Glaciers on the Tibetan Plateau are classified into two types: continental and maritime. Continental glaciers are located in dry and cold environments, and their ice temperature is below $0^{\circ} \mathrm{C}$ (Huang and others, 1982; Huang, 1990); the distribution of maritime glaciers is limited to the wet and comparatively warm southeastern part of the Tibetan Plateau. In a case-study of a continental-type glacier, Ageta and others (1989) pointed out that almost no meltwater is discharged out of the accumulation zone of Chongce Ice Cap in west Kunlun, northern periphery of the Tibetan Plateau. On the Tibetan Plateau, glacier melting and refreezing occur even at altitudes above $6000 \mathrm{~m}$ a.s.l., because of the strong summer radiation associated with the low latitude and low ice temperature derived from the cold continental climate in winter. Meltwater refreezing is a key process controlling the behaviour of meltwater, specifically whether it becomes glacier runoff or is retained inside the glacier. However, no quantitative process study has been made to clarify the relation between mass balance and meltwater refreezing for glaciers on the Tibetan Plateau.

A research project, CREQ (Cryosphere Research on Qingzang Plateau) was planned to clarify the role of snow and ice in the water cycle on the Tibetan Plateau (Ageta and others, 1991, 1994). As part of the project, intensive observations were carried out to clarify the processes and the influences of meltwater refreezing on the mass balance of Xiao (small) Dongkemadi Glacier, Tanggula Mountains, between May and September 1993 (Seko and others, 1994). During this intensive observation period (IOP), surface balance, percolating water, ice temperature and superimposed ice accumulation were measured. The temporal and spatial variation of the meltwater refreezing are evaluated from these data, and the quantitative influence on the mass balance is discussed in this paper.

\section{LOCATION, GLIMATE AND OBSERVATIONS}

The Tanggula Mountains are located in the central Tibetan Plateau $\left(33^{\circ} \mathrm{N}, 92^{\circ}\right.$ E; Fig. 1). Xiao Dongkemadi Glacier, where the present study was made, is located in the middle of the mountain range. Its terminus and top altitudes, length, and area are 5380 and $5926 \mathrm{~m}$ a.s.l., $2.8 \mathrm{~km}$ and $1.77 \mathrm{~km}^{2}$, respectively (Fig. 2) The average surface inclination is about $10^{\circ}$, facing south, and there are few crevasses and no icefall. The equilibrium-line altitude (ELA) is usually around $5600 \mathrm{~m}$ a.s.l. 


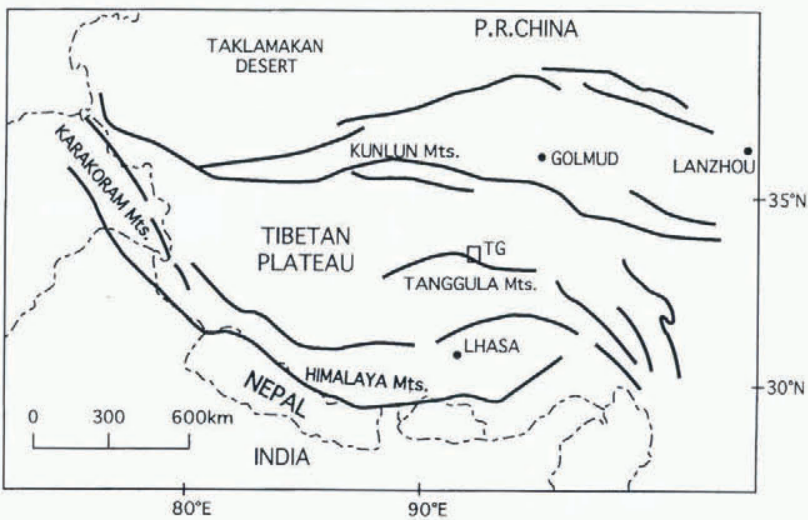

Fig. 1. Location map of study area. TG denotes Tanggula mountain area including Xiao Dongkemadi Glacier.

The mean annual air temperature at $5600 \mathrm{~m}$ a.s.l. is about $-10^{\circ} \mathrm{C}$ since October 1991 , with an annual range exceeding $20^{\circ} \mathrm{C}$. Daily mean air temperatures were above $0^{\circ} \mathrm{C}$ for only $30 \mathrm{~d}$ in a year, mainly in August. The average short-wave radiation flux from June to August 1993 was $280 \mathrm{~W} \mathrm{~m}^{-2}$, which is stronger than that of almost all mid-latitude glaciers (Ohmura and others, 1992). In this climatic environment, considerable amounts of meltwater can be expected to form in the accumulation zone in spite of the low summer air temperatures. It is thought that winter cooling is sufficient to refreeze the considerable amount of meltwater formed during the following summer.

The measured parameters, the frequency of observation and the altitude of the measurement sites are summarized in Table 1. Twenty-seven stakes have been installed for mass-balance measurement since 1989. Detailed mass-balance analysis is aided by automatic snow-depth gauges at 5480, 5600 and $5700 \mathrm{~m}$ a.s.l., and ice-temperature recorders installed at 5480, 5600 and $5680 \mathrm{~m}$ a.s.l. The surface level relative to the stake, the relative level of the interface between snow and superimposed ice (ice surface), the amount of percolated water in the snow layer, the ice temperature, and precipitation

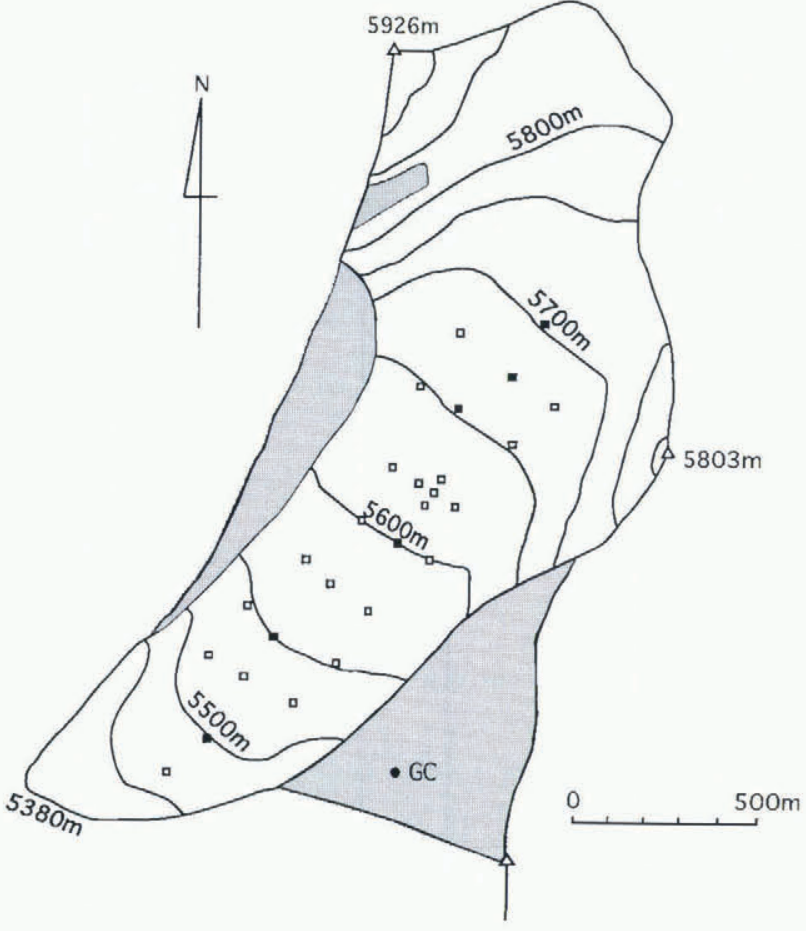

Fig. 2. Location map of stakes (open square) and the sites where superimposed ice was measured intensively (solid square) on Xiao Dongkemadi Glacier. GC denotes Glacier Camp. Meteorological station was located at 5600 m a.s.l. (solid square).

were measured during the IOP, from May to September 1993, to evaluate the influence of meltwater refreezing on the mass balance.

\section{OBSERVATIONAL RESULTS}

\section{Pit observations and $5 \mathrm{~m}$ ice cores}

Figure 3 a shows pit observations performed at $5700 \mathrm{~m}$ a.s.l. The difference of surface position of each

Table 1. Observations on Xiao Dongkemadi Glacier. The IOP was May-September 1993

\begin{tabular}{|c|c|c|}
\hline Parameter & $\begin{array}{l}\text { Site altitude } \\
\text { ma.s.l. }\end{array}$ & Period \\
\hline
\end{tabular}

Surface level

Meteorological elements: air temperature; relative humidity; wind speed; wind direction; global radiation (up and down);

all radiation (up and down) $\quad 5600$

Ice temperature

Snow-pit studies: stratigraphy; density; grain-size; liquid-water content

Percolating water

Precipitation

5600

$5480,5540,5670,5700$

From May 1989

IOP

$1 \mathrm{~d}$

$\approx 5 \mathrm{~d}$

$5680,5600,5480$

$5700,5670,5600$

5600,5700

$5500^{*}$
From Sept. 1991

From Oct. 1992

IOP

IOP

IOP
$1 \mathrm{~h} ; 10 \mathrm{~min}$ in $\mathrm{IOP}$ $\approx 10 \mathrm{~d}$

$\approx 10 \mathrm{~d}$

$\approx 10 \mathrm{~d}$

Twice a day

\footnotetext{
* Glacier Camp.
} 

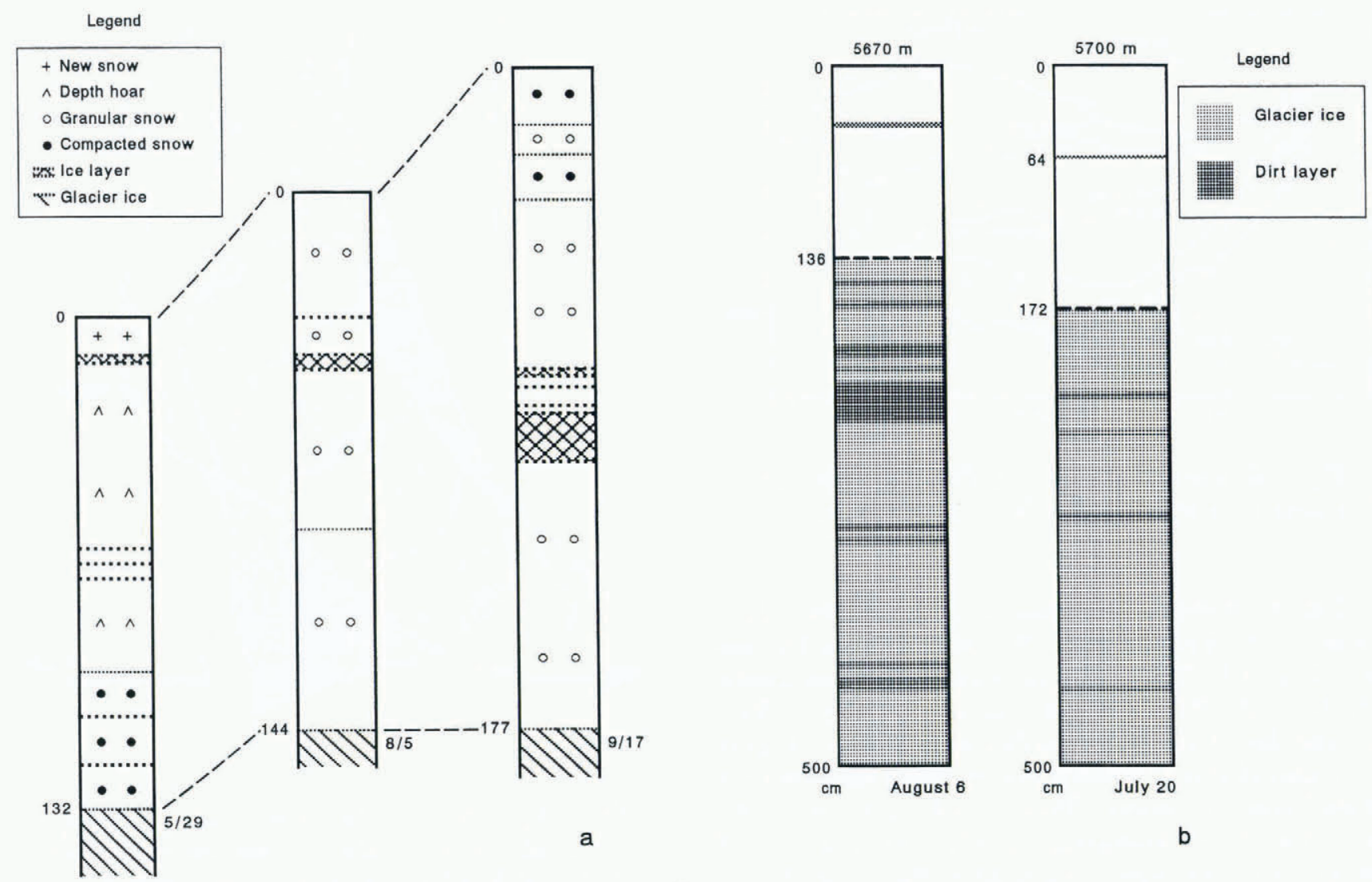

Fig. 3. Strata of snow observed at 5700 m a.s.l. (a), and $5 \mathrm{~m}$ samples taken at 5670 and $5700 \mathrm{~m}$ a.s.l. (b), in 1993. Glacier ice exists continuously below the dashed lines of $(b)$.

column is shown in this figure on the basis of stakemeasurement data; the remarkable rising of the ice surface from 29 May to 5 August can be seen. As seen from the $5 \mathrm{~m}$ ice cores in Figure $3 \mathrm{~b}$, there is continuous glacier ice beneath snow less than $2 \mathrm{~m}$ thick, even at the highest observation point in the accumulation zone. This fact means that the superimposed ice formation occurs in almost the whole accumulation zone of the glacier.

\section{Levels of surface and ice surface}

Figure 4 shows the variation of the surface level and icesurface level relative to the mass-balance stake at 5600 ma.s.l. from October 1992 to September 1993. The surface level was obtained by an automatic snowdepth gauge using photo diodes (KADEC SNOW) and by manual stake measurements. The variation of surface level during winter (October-March) is rather small compared with that during summer (April-September), except for occasional increases and decreases. The largest variations of surface level are associated with the accumulation and ablation that took place between June and August.

The ice-surface level was calculated from the surface level and the snow-layer thickness observed in pits. The ice surface is clearly discernible, since the snow thickness is less than $2 \mathrm{~m}$. A rising ice surface implies accumulation of superimposed ice by refreezing of meltwater. During winter, there is no apparent change in the ice surface. Although the ice surface is found to rise slightly at the beginning of June, it remains stationary until mid-July

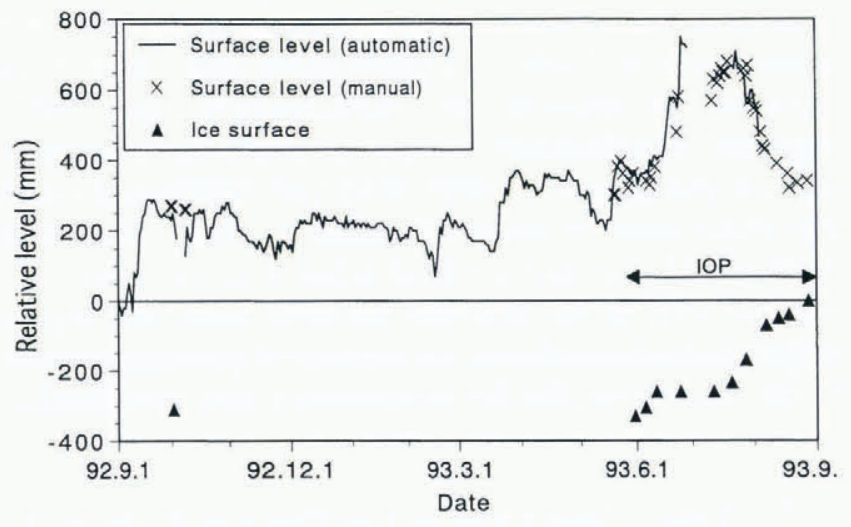

Fig. 4. The variation of surface level and ice-surface level relative to the mass-balance stake at 5600 ma.s.l. on Xiao Dongkemadi Glacier from September 1992 through August 1993.

and then undergoes a remarkable rise during the 1 month period between late July and the end of August, corresponding to the rapid surface-level decrease.

Figure 5 shows variations of the ice surface during the IOP at four altitudes (5480, 5540, 5670 and $5700 \mathrm{~m}$ a.s.l.). The largest rise of the ice surface was observed at $5670 \mathrm{~m}$ a.s.l. in the accumulation zone, not at the highest site $(5700 \mathrm{~m}$ a.s.l.). In the ablation zone $(5540 \mathrm{~m}$ a.s.1.), a rise of ice surface was observed in the early part of the IOP, but melting of the ice surface occurred during August when it was exposed. At the lowest elevation 


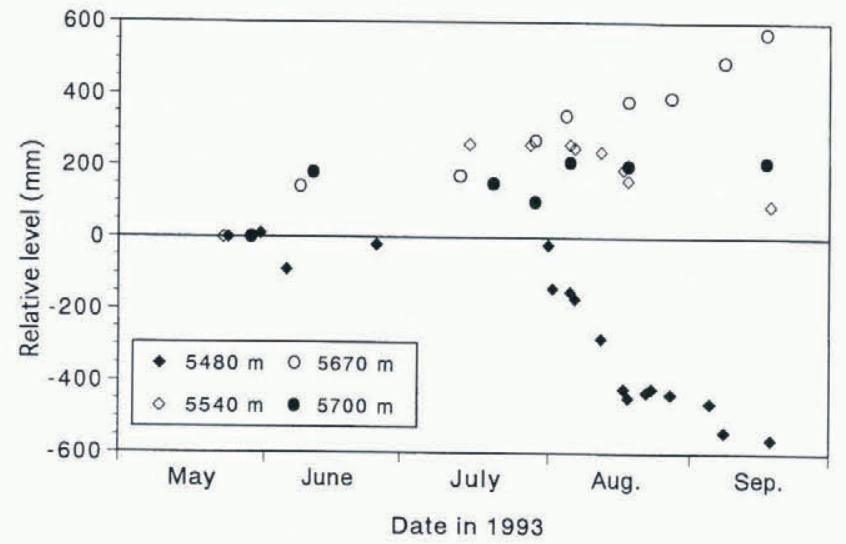

Fig. 5. The variation of ice-surface level obtained by stake and pit measurements at four altitudes on Xiao Dongkemadi Glacier during the IOP. The relative level $0 \mathrm{~mm}$ corresponds to the first measurement at each site in late May.

(5480 $\mathrm{m}$ a.s.1.), the exposed ice surface lowered throughout the IOP.

\section{Percolating water}

Figure 6 shows the temporal variation of percolatingwater flux at two altitudes. Water percolation was assessed by repeated weighing bottles, set $10-20 \mathrm{~cm}$ below the snow surface, at intervals of several days, in a manner similar to that of Ageta and others (1989). At $5600 \mathrm{~m}$ a.s.l., the flux increased drastically during late July, which corresponds to the onset of surface lowering, and ice-surface rising, as shown in Figure 4. The percolating-water flux decreased rapidly at the end of August. At $5700 \mathrm{~m}$ a.s.l., considerable water percolation occurred only during August. During the IOP, the total flux of percolating water measured at 5700 and $5600 \mathrm{~m}$ a.s.l. was 149 and $408 \mathrm{~mm}$ w.e., respectively.

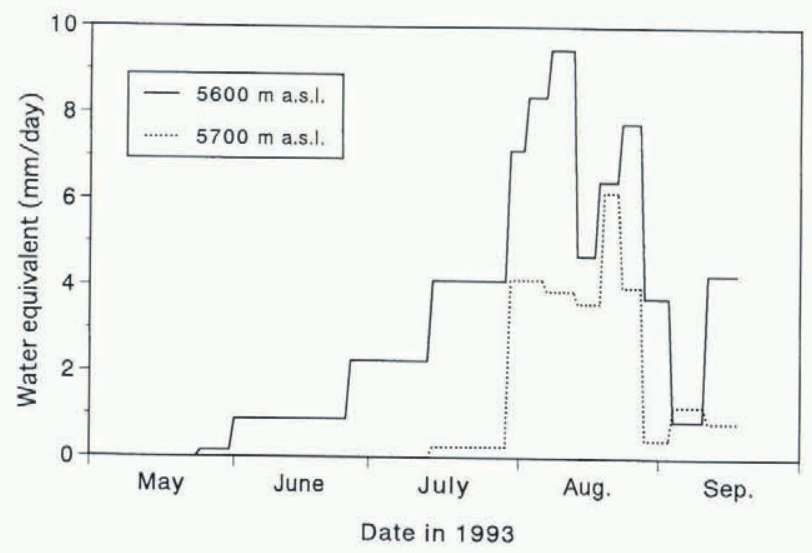

Fig. 6. The mean daily amounts of water percolation for each observation span at two altitudes on Xiao Dongkemadi Glacier during the IOP.

\section{Ice temperature}

Figure 7 shows the ice-temperature profile from October 1992 to September 1993, recorded at $5600 \mathrm{~m}$ a.s.l. The

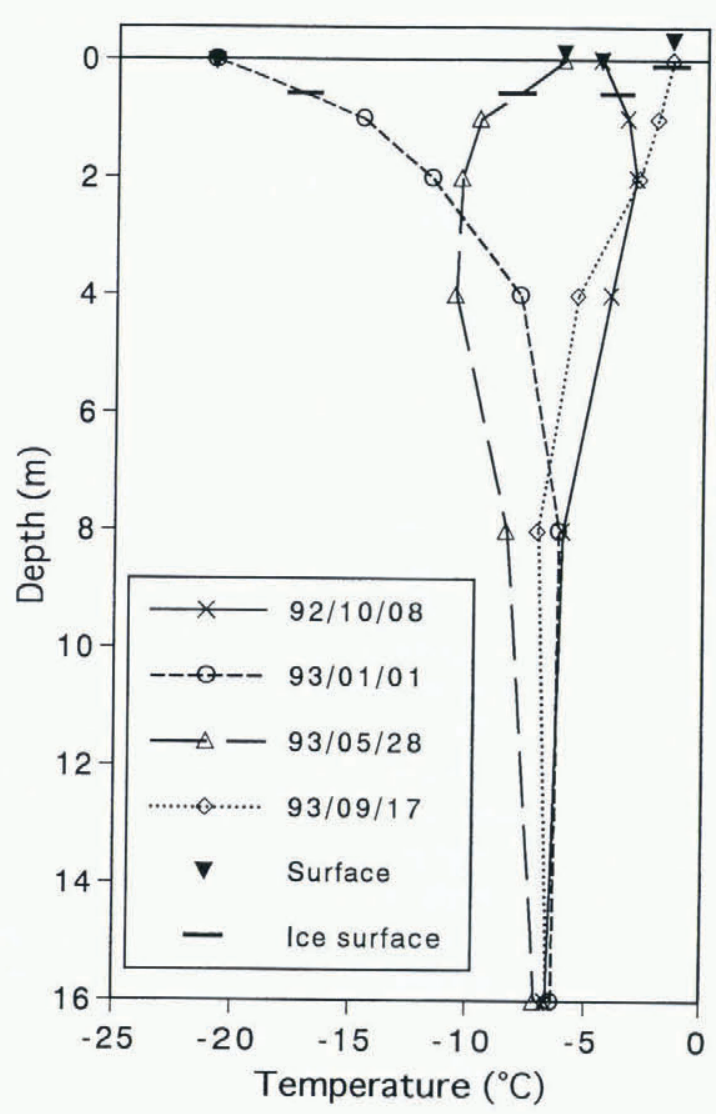

Fig. 7. Variation of snow and ice temperature of Xiao Dongkemadi Glacier at 5600 m a.s.l. from October 1992 to September 1993. The depth $0 \mathrm{~m}$ corresponds to the surface on 8 October 1992.

ice-temperature profile during January shows strong cooling near the surface. Then the surface temperature increases up to the end of May without surface melting. During almost the whole of the IOP, the temperature of the snow layer was $0^{\circ} \mathrm{C}$, and ice temperature below the ice surface gradually increased. Because the glacier ice is continuous below the ice surface, percolating water cannot infiltrate there. Therefore, the ice-temperature increase during the melting period is mainly due to conduction of the latent heat released at the ice surface as percolating water refreezes.

\section{QUANTITATIVE ESTIMATION OF SUPERIMPOSED ICE}

The data obtained on percolating water, surface and icesurface level changes, and ice temperature clearly indicate the accumulation of superimposed ice. In order to quantitatively evaluate the superimposed ice growth, three related quantities were calculated from the observational data. These are referred to as "potential refrozen water", "actual refrozen water" and "percolating water".

\section{Formulas}

Assuming that the warming of the underlying glacier ice is caused only by the latent heat released at the ice surface 
associated with refreezing of percolating water, the amount of refrozen water can be calculated from the variation of ice temperature as:

$$
R_{\mathrm{p}}=\int_{0}^{z_{\mathrm{c}}} \frac{\rho_{\mathrm{i}} C_{\mathrm{i}}}{L} \Delta T(z) \mathrm{d} z
$$

where $R_{\mathrm{p}}$ is the amount of refrozen water $\left(\mathrm{kg} \mathrm{m}^{-2}\right.$, numerically equal to mm w.e.); $z_{\mathrm{c}}$ is the depth $(\mathrm{m})$ where the annual amplitude of ice temperature is less than $0.1^{\circ} \mathrm{C}$ taken as $20 \mathrm{~m}$, based on a thermal diffusivity for glacier ice of $\left.1.16 \times 10^{-6} \mathrm{~m}^{2} \mathrm{~s}^{-1}\right) ; \rho_{\mathrm{i}}$ is the density of superimposed ice, $870 \pm 40 \mathrm{~kg} \mathrm{~m}^{-3}$, based on the range of ice density; $C_{\mathrm{i}}$ is the specific heat capacity of ice, $2009 \mathrm{~J} \mathrm{~kg}^{-1}{ }^{\circ} \mathrm{C}^{-1} ; L$ is the latent heat of fusion for ice, $3.35 \times 10^{5} \mathrm{~J} \mathrm{~kg}^{-1} ; \Delta T(z)$ is the change of ice temperature $\left({ }^{\circ} \mathrm{C}\right)$ at depth $z(\mathrm{~m})$ over the observation interval. The amount of refrozen water calculated from the variation of ice temperature represents the maximum ability of the ice body to refreeze percolating water. Therefore, we call this amount "potential refrozen water".

On the other hand, refreezing of percolating water causes a rise of the ice surface. The "actual frozen water" $\left(R_{\mathrm{a}}\right)$ amount is calculated from the increase of ice surface as:

$$
R_{\mathrm{a}}=\left(\rho_{\mathrm{i}}-\rho_{\mathrm{s}}\right) \Delta I
$$

where $\rho_{\mathrm{i}}$ is the density of superimposed ice, $870 \pm$ $40 \mathrm{~kg} \mathrm{~m}^{-3}, \rho_{\mathrm{s}}$ is the average snow density, $380 \mathrm{~kg} \mathrm{~m}^{-3}$, which was obtained from pit observations, and $\Delta I$ is the change of ice-surface level during an observation interval. The "actual refrozen water" calculated by Equation (2) is equal to the accumulation of superimposed ice $\left(c_{\mathrm{i}}\right)$.

Superimposition of ice does not occur without water, even though the glacier ice is sufficiently cold. Thus, "percolating water" is important for superimposed ice formation.

\section{Temporal variation}

Figure 8 shows the cumulative variation of "potential refrozen water", "actual refrozen water" and "percolat-

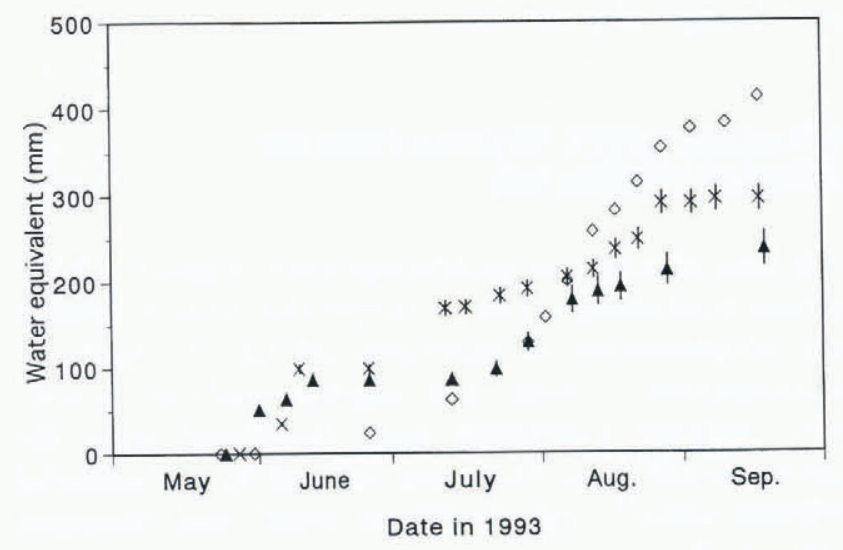

Fig. 8. The cumulative variation of "actual refrozen water" (triangle), "potential refrozen water" (cross) and "percolating water" (square) at 5600 ma.s.l. on Xiao Dongkemadi Glacier during the IOP. Each vertical bar denotes the error based on the density assumption. ing water" at $5600 \mathrm{~m}$ a.s.l. Although "percolating water" amount was not observed, the amounts of "actual refrozen water" and "potential refrozen water" increased at the end of May. This unreasonable variation might be caused by the error of percolating-water measurement. However, since the "percolating water" amount is small up to the middle of July, the "actual refrozen water" amount did not increase during this period, and the glacier ice was warmed by the temperature gradient above $4 \mathrm{~m}$ depth on 28 May in Figure 7. From the end of July to early August, the "actual refrozen water" quantity increased rapidly in association with the increase of "percolating water". Because the possibility of superimposed ice formation depends on the heat conduction of ice, the amount of "actual refrozen water "cannot exceed that of "potential refrozen water", even in conditions where "percolating water" is supplied sufficiently, as it was during August.

\section{Altitudinal distribution}

Figure 9 shows the altitudinal distribution of "percolating water", "potential refrozen water" and "actual refrozen water" during the IOP. The amount of percolating water at $5700 \mathrm{~m}$ a.s.l. is less than half of that at $5600 \mathrm{~m}$.a.s.l. Although we could not measure the percolating water in the ablation zone due to thin or no snow layer, it is probable that the amount of meltwater was more than that in the accumulation zone. The total amount of "potential refrozen water" was calculated from the icetemperature profile for the melting period $28 \mathrm{May}-17$

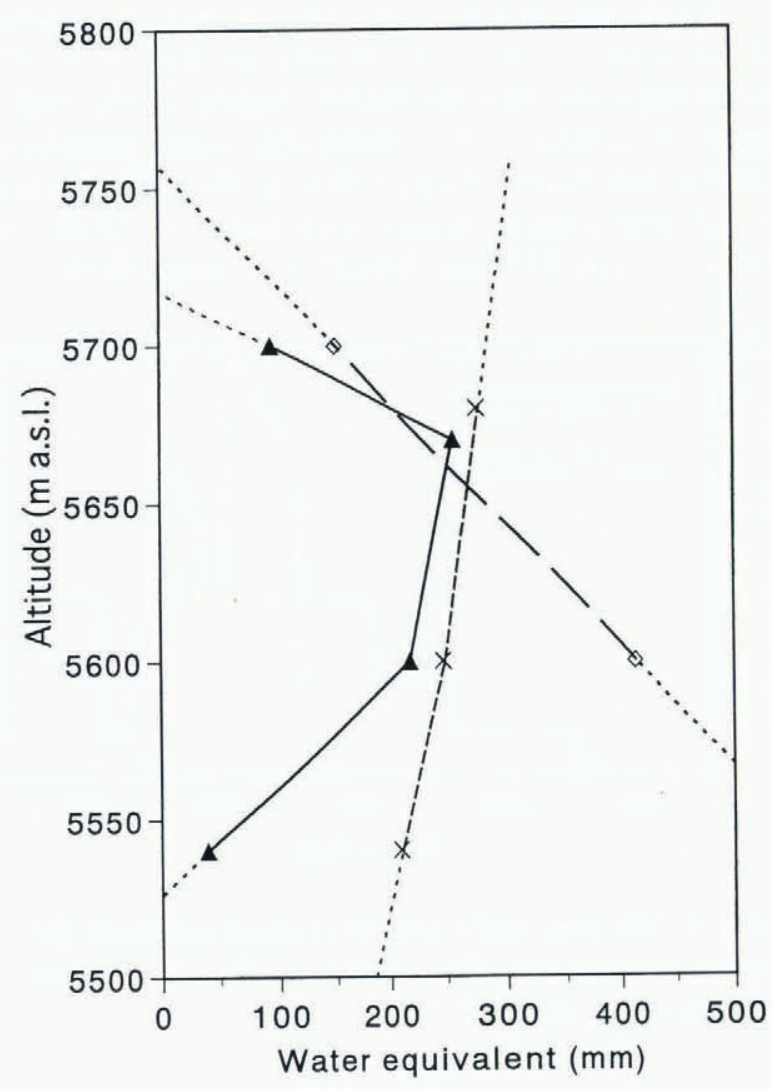

Fig. 9. The altitudinal distribution of "actual refrozen water" (triangle), "potential refrozen water" (cross) and "percolating water" (square) on Xiao Dongkemadi Glacier during the IOP. 
September 1993 (Fig. 7), at three altitudes. This altitudinal profile shown in Figure 9 results from the glacier ice in the accumulation zone being slightly colder than in the ablation zone at the end of May.

At the highest site for ice-temperature measurement (5680 $\mathrm{m}$ a.s.l.), the glacier ice was cold enough to freeze percolating water early in the IOP. But as shown in Figure 6, melting started in late July, so the amount of "actual refrozen water" is limited by that of "percolating water". With a decrease in altitude, "actual refrozen water" increases as rapidly as "percolating water" until $5670 \mathrm{~m}$ a.s.l. Below $5670 \mathrm{~m}$ a.s.l., even when the supply of "percolating water" is sufficient, the amount of "actual refrozen water" is limited by the "potential refrozen water". As shown in Figure 5, the ice-surface level at $5540 \mathrm{~m}$ a.s.l. became lower during August due to ablation, although a slight increase could be found in the early IOP, and no ice-surface rise was observed at $5480 \mathrm{~m}$ a.s.l. Even if "potential refrozen water" and meltwater are enough, "actual refrozen water" cannot be retained at the end of the intensive melting period below $5540 \mathrm{~m}$ a.s.l., since meltwater runs off over the exposed ice surface, or ablation of the exposed refrozen water occurs at the glacier surface.

\section{SUPERIMPOSED ICE AND MASS BALANCE}

A certain amount of summer meltwater refreezes up to the following winter even on temperate glaciers. Therefore it is necessary to discuss the quantitative influence of superimposed ice on mass balance and discharge.

The balance, $b$ (mmw.e.), during a given period, including refrozen water, is obtained from:

$$
b=\Delta S \rho_{\mathrm{s}}+\Delta I \rho_{\mathrm{i}}
$$

where $\Delta S$ and $\Delta I$ are the differences of snow thickness and ice-surface level in meters during a given period, $\rho_{\mathrm{s}}$ is the snow density obtained from pit observations $\left(\mathrm{kg} \mathrm{m}^{-3}\right)$, and $\rho_{\mathrm{i}}$ is the density of the superimposed ice, $870 \mathrm{~kg} \mathrm{~m}^{-3}$.

Since no rainfall occurred in the accumulation zone because of low air temperatures, the melt ablation, $a_{\mathrm{m}}$ (mmw.e., negative value), can be considered to be the same as the "percolating water". Although we could not measure the percolating water in the ablation zone due to thin or no snow layer, it is thought that $a_{\mathrm{m}}$ increases rapidly with a decrease in altitude because of the lower albedo in the ablation zone.

In regard to loss by evaporation $\left(a_{\mathrm{e}}\right)$, Ohno and Ohata (1994) calculated the amount of evaporation at $5600 \mathrm{~m}$ a.s.l. during the same period in 1992 to be $-62 \mathrm{~mm}$ w.e. This amount does not change so much at the different altitudes and between 1992 and 1993 (personal communication from H. Ohno, 1994).

The accumulation to the glacier surface due to precipitation $\left(c_{\mathrm{p}}\right)$ is calculated as:

$$
c_{\mathrm{p}}=b-R_{\mathrm{a}}-a_{\mathrm{m}}-a_{\mathrm{e}} .
$$

The average surface accumulation for the positivebalance area (above $5550 \mathrm{ma}$ a.l.) was $469 \mathrm{~mm}$ w.e. during the IOP.
Figure 10 shows the altitudinal distribution of melt ablation $\left(a_{\mathrm{m}}\right)$, the observed balance and averaged balance for $50 \mathrm{~m}$ altitude spans $(b)$, superimposed ice accumulation $\left(c_{\mathrm{i}}\right)$ and the areal distribution of the glacier zones. The altitude where equilibrium existed during the IOP was located at about $5550 \mathrm{ma}$ a.s. The meltwater was not discharged above $5660 \mathrm{ma}$ a.s.l., as shown in Figure 9. The total amounts of superimposed ice accumulation, melt ablation and surface accumulation during the IOP were calculated for the positive-balance area (above $5550 \mathrm{~m}$ a.s.l.) using the averaged amounts for $50 \mathrm{~m}$ altitude spans and the areal distribution of the glacier zones. The values obtained were $1.58 \times 10^{5}$, $-2.60 \times 10^{5}$ and $6.06 \times 10^{5} \mathrm{~m}^{3}$, respectively. This means that $61 \%$ of the meltwater generated above $5550 \mathrm{~m}$ a.s.l. is trapped by refreezing and is not discharged out of the glacier. During this period, the $26 \%$ of accumulated snow above $5550 \mathrm{~m}$ a.s.l. was displaced from the glacier surface onto the ice surface by superimposition of ice.

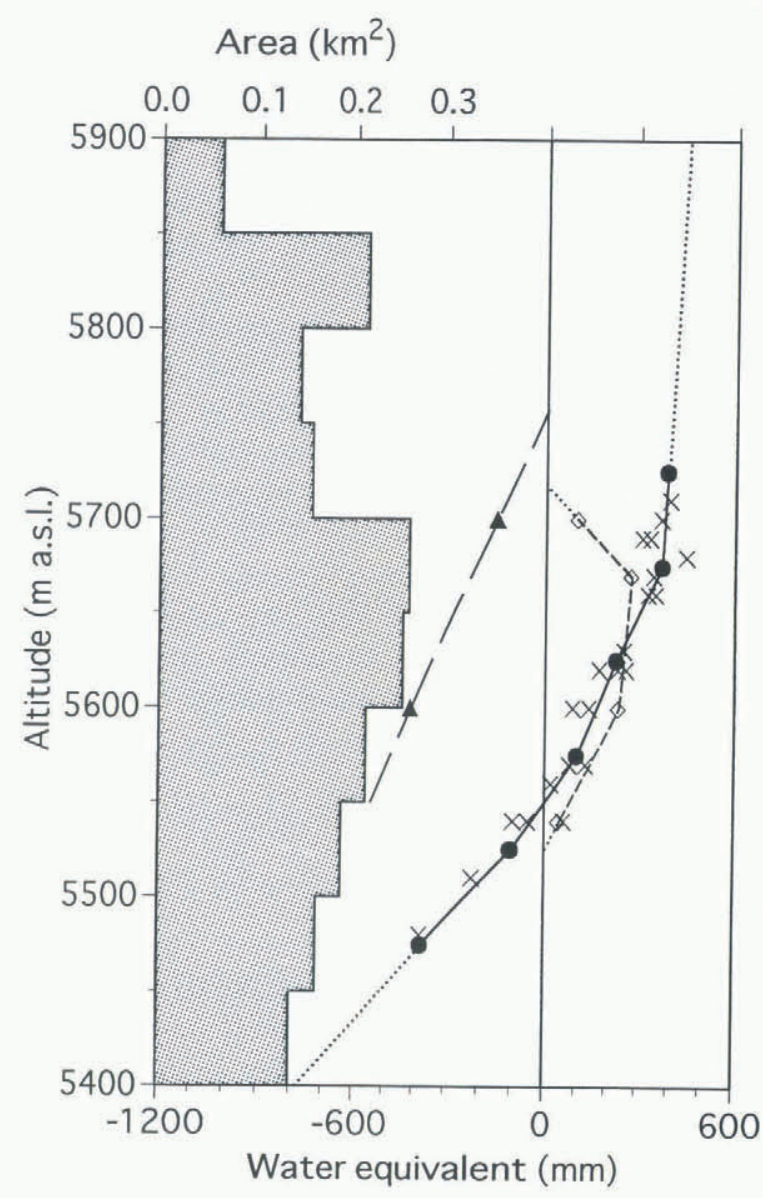

Fig. 10. The altitudinal distribution of the observed balance (cross), averaged balance for $50 \mathrm{~m}$ altitude span (circle), melt ablation (triangle), superimposed ice (square) and the glacier areas (shadow) on Xiao Dongkemadi Glacier during the IOP.

\section{CONCLUDING REMARKS}

On Xiao Dongkemadi Glacier, a typical continental glacier on the Tibetan Plateau, about $60 \%$ of the total meltwater generated in the accumulation zone for the 
period May-September was trapped at the ice surface and was not discharged out of the glacier. As a result, about $26 \%$ of the accumulated snow was displaced from surface onto the ice surface in the accumulation zone. These facts indicate that superimposed ice formation plays a significant role in the retention of water by glaciers under conditions of low precipitation.

Superimposition of ice is controlled by both melting and ice temperatures. Melting is caused by strong solar radiation in spite of the low-temperature environment. Ice temperature is lowered in the previous winter. The mass balance of glaciers in the Himalayas is primarily affected by the summer air temperature (Ageta, 1983) because the main annual accumulation and ablation occur simultaneously during the summer monsoon season, and air temperature controls the phase of precipitation. In regard to continental glaciers on the Tibetan Plateau, the surface mass balance is also controlled mainly by summer accumulation and ablation, but the cold environment of winter also plays a significant role, since the amount of superimposed ice cannot be neglected in the mass balance.

The existence of a thin snow layer significantly increases the retention of cold ice temperatures in winter within the glacier. The snow layer is kept thin by surface melting and ice-surface rising in the melting season. On the other hand, it also can happen that the thin snow layer disappears soon after the beginning of the melting season, exposing the ice surface to intense solar radiation, even in the accumulation zone. Under the strong radiative environment, a decrease of albedo will cause a drastic increase of ablation. Actually, such conditions of the glacier surface have been observed in 1991 and 1995.

Much remains to be done to further quantify the processes, and the relationship between meltwater refreezing and winter meteorological conditions. The relation between melting and summer meteorological conditions should also be studied further in order to construct mass-balance models for continental-type glaciers on the Tibetan Plateau.

\section{ACKNOWLEDGEMENTS}

The authors are very grateful to all CREQ members for useful and interesting advice as well as logistic support during the observations. Furthermore, we are especially grateful to Dr L. E. Goodrich (Institute for Research in
Construction, National Research Council of Canada) for useful suggestions and discussions. Financial support for the Japanese side in this study came from the International Scientific Research Program (03041038) of a Grant-in-Aid for Scientific Research and IGBP Scientific Research, both from the Ministry of Education, Science and Culture, Japan. On the Chinese side, this project was supported by the Natural Science Foundation of China.

\section{REFERENCES}

Ageta, Y. 1983. Characteristics of mass balance of the summer accumulation type glacier in the Nepal Himalaya. Seppyo, 45(2), 81-105. [In Japanese with English summary.]

Ageta, Y., Zhang Wenjing and M. Nakawo. 1989. Mass balance studies on Chongce Ice Cap in the west Kunlun Mountains. Bull. Glacier Res. 7, $37-43$

Ageta, Y. and 7 others. 1991. Glaciological studies on Qingzang Plateau, 1989. Part 2. Glaciology and geomorphology. Bull. Glacier Res. 9, 27-32.

Ageta, Y., Yao Tandong and T. Ohata. 1994. Outline of the study project on the role of snow and ice in the water cycle on Qingzang Plateau, 1990-93. Bull. Glacier Res. 12, 87-94.

Baird, P.D. 1952. The glaciological studies of the Baffin Island Expedition, 1950. Part I: Method of nourishment of the Barnes Ice Cap. J. Glaciol., 2(11), 2-9, 17-19.

Bazhev, A. B. 1973. Infiltration and run-off of melt water on glaciers. International Association of Scientific Hydrology Publication 95 (Symposium at Cambridge 1969 - Hydrology of Glaciers), 245-249.

Braithwaite, R. J., M. Laternser and W. T. Pfeffer. 1994. Variations of near-surface firn density in the lower accumulation area of the Greenland ice sheet, Pâkitsoq, West Greenland. J. Glaciol., 40 (136), $477-485$.

Huang Maohuan. 1990. On the temperature distribution of glaciers in China. 7. Glaciol., 36 (123), 210-216.

Huang Maohuan, Wang Zhongxiang and Ren Jiawen. 1982. On the temperature regime of continental type glaciers in China. J. Glaciol., 28 $(98), 117-128$.

Koerner, R. M. 1970. Some observations on superimposition of ice on the Devon Island ice cap, N.W.T. Canada. Geogr. Ann., 52A(1), 57-67.

Ohmura, A., P. Kasser and M. Funk. 1992. Climate at the equilibrium line of glaciers. J. Glaciol., 38(130), 397-411.

Ohno, H. and T. Ohata. 1994. [Annual evaporation from continental type glaciers.] Seppyo, 56(4), 341-351. [In Japanese with English summary.]

Seko, K., Pu Jianchen, K. Fujita, Y. Ageta, T. Ohata and Yao Tandong. 1994. Glaciological observations in the Tanggula Mts., Tibetan Plateau. Bull. Glacier Res, 12, 57-67.

Trabant, D. C. and L. R. Mayo. 1985. Estimation and effects of internal accumulation on five glaciers in Alaska. Ann. Glaciol., 6, 113-117.

Wakahama, G., D. Kuroiwa, T. Hasemi and C. S. Benson. 1976. Field observations and experimental and theoretical studies on the superimposed ice of McCall Glacier, Alaska. 7. Glaciol., 16(74), $135-149$.

Ward, W.H. 1952. The glaciological studies of the Baffin Island Expedition, 1950. Part II: The physics of deglaciation in central Baffin Island. J. Glaciol., 2(11), 9-22. 